\title{
ŚWIADOMOŚĆ EKOLOGICZNA MŁODYCH LUDZI
}

\author{
Agnieszka Kwiatek, Maja Skiba \\ Politechnika Częstochowska \\ Wydział Zarządzania
}

\begin{abstract}
Streszczenie: W opracowaniu jako główny problem został poruszony sposób pojmowania świadomości ekologicznej współczesnej młodzieży. Obecnie funkcjonujące różnego rodzaju projekty ekologiczne wprowadzane już od najniższych stopni edukacji oraz liczne kampanie społeczne pozwalają przypuszczać, iż większość młodych ludzi powinna posiadać chociażby minimalny zakres wiedzy na ten temat. Celem pracy, w oparciu o to założenie, jest ocena stopnia świadomości ekologicznej młodzieży, tzn. jakie znaczenie ma dla nich wiedza ekologiczna oraz na ile jest stosowana w praktyce? Szczególnie w obszarach takich jak racjonalne wykorzystanie zasobów, proekologiczne zachowania, gospodarka odpadami oraz ogólny stosunek do ekologii. Również w sferze zainteresowań pozostają ich zachowania w kwestii decyzji konsumenckich i ekonomii gospodarowania odpadami. W badaniach posłużono się wywiadem skategoryzowanym.
\end{abstract}

Słowa kluczowe: świadomość, świadomość ekologiczna, wiedza ekologiczna

DOI: $10.17512 /$ znpcz.2017.4.2.10

\section{Wprowadzenie}

Twierdzenie, iż poprzez kształtowanie jakości przyrody mamy bezpośredni wpływ na jakość swojego życia, wydaje się być oczywistością. Jednakże z różnych przyczyn - ekonomicznych, kulturowych, edukacyjnych itp. - większość ludzi nie stosuje się do tej zasady (zob.: TNS 2014).

Przy omawianiu podejmowanej tematyki źródeł zachowań ekologicznych należy jednocześnie przywołać obraz człowieka nastawionego na realizację własnych interesów, racjonalnie kalkulującego korzyści i straty swoich działań, tzw. homo oeconomicus, który to zdominował nauki ekonomiczne. Funkcjonuje on również w koncepcjach dylematów społecznych, w których rozważany jest konflikt między interesem indywidualnym a zbiorowym oraz między interesem krótkofalowym i długofalowym, również w kwestii podejmowanej w opracowaniu tematyki dylematów ekologicznych. Teorie te, wśród których możemy wymienić koncepcje „tragedii dóbr wspólnych” D. Hardina czy „logiki działań kolektywnych” M. Olsona, są wykorzystywane również w rozwiązywaniu problemów ekologicznych. Problem ekologiczny jest ujmowany w takich analizach jako przypadek należący do szerszej kategorii problemów społecznych (Górnicki 2012, s. 282).

Systemy wartości, oceny, przejmowane normy prowadzą do kształtowania się nie tylko indywidualnej wiedzy na temat otaczającego nas świata przyrody, ale także określonego stosunku do niej, zachowań i postaw. Z tego też względu 
ogromną rolę odgrywa kształtowanie wiedzy ekologicznej poszczególnych jednostek szczególnie od najmłodszych lat.

Florian Znaniecki, przedstawiciel socjologii humanistycznej, poprzez ekologię człowieka rozumiał potrzebę uwzględnienia świata ludzkich znaczeń i wartości jako elementów środowiska regulujących zachowanie człowieka (Znaniecki 1938, s. 90). Człowiek jako organizm biologiczny obdarzony rozumem pozostaje osadzony w dwóch silnych kontekstach: biosferze i kulturosferze (z podkreśleniem przy tym, iż związki człowieka ze środowiskiem przyrodniczym są nierozerwalne). Może on bezpośrednio na nią wpływać i z niej korzystać, a ona kształtuje jego zachowania i postawy.

Większość badań wskazuje, że Polacy z roku na rok zdają sobie coraz bardziej sprawę z tych zależności. Rośnie ich tzw. świadomość ekologiczna, czyli stopień zainteresowania tematyką ochrony środowiska, poziom aprobaty degradacji środowiska naturalnego jako ceny wzrostu ekonomicznego i poziom wiedzy na temat różnych metod pozytywnego wpływu na stan środowiska (TNS OBOP 2011, s. 16).

Świadomość ekologiczna jest zespołem informacji i przekonań na temat środowiska przyrodniczego oraz postrzeganiem związków między stanem i charakterem środowiska przyrodniczego a warunkami i jakością życia człowieka (Burger 1986, s. 375).

Obecnie funkcjonujące różnego rodzaju projekty ekologiczne oraz kampanie społeczne wprowadzane już od najniższych stopni edukacji pozwalają przypuszczać, iż większość młodych ludzi powinna posiadać chociażby minimalny zakres wiedzy na ten temat. Ponieważ posiadana wiedza i umiejętność jej stosowania w praktyce świadczą o poziomie świadomości, autorki w oparciu o to założenie chcą uzyskać odpowiedzi na następujące zagadnienia:

- Jakie znaczenie ma dla współczesnej młodzieży świadomość ekologiczna?

- Jaki jest zakres wiedzy ekologicznej i potrzeba jej zdobywania?

- Na ile wiedza ta jest stosowana przez nich w praktyce?

Odpowiedzi na tak postawione pytania zostały uzyskane podczas wywiadów (96 wywiadów skategoryzowanych) z młodzieżą w wieku od 19 do 23 lat.

Głównym celem opracowania jest odpowiedź na powyższe pytania. Natomiast obszarami zainteresowania są między innymi: racjonalne wykorzystanie zasobów (tj. paliwa, metal, woda, energia elektryczna itp.), proekologiczne zachowania konsumenckie młodzieży (zachowania podczas zakupów, wybór produktów, opakowań), gospodarka odpadami (wyrzucanie, segregacja śmieci itp.). Oraz ich ogólny stosunek do ekologii (wiedza ekologiczna, wiedza nt. relacji zdrowie a jakość życia - ochrona środowiska itp.).

\section{Teoretyczne ujęcie pojęć: „świadomość" i ,świadomość ekologiczna”}

W celu przybliżenia kluczowych dla opracowania terminów świadomości i świadomości ekologicznej autorki opracowania dokonały krótkiej analizy literatury przedmiotu, przywołując niektóre koncepcje teoretyczne związane z tymi pojęciami. 
Świadomość, jak pisze R. Gregory, to stan lub zdolność posiadania wiedzy, czyli warunek myśli, odczuć i woli oraz zjawisko im towarzyszące, a także rozpoznawanie przez myślący podmiot własnych czynów lub uczuć (Gregory 2000, s. 12).

W ujęciu S. Sutherlanda świadomość jest pojmowana jako dokonywanie spostrzeżeń, myśli i uczuć, zdawanie sobie z czegoś sprawy. Świadomość jest zjawiskiem tyle fascynującym, co nieuchwytnym. Oznacza to, że nierealnym jest dokładne określenie, czym ona jest, lecz można dociekać, w jaki sposób działa lub dlaczego powstała (por.: Sutherland 1996).

S.L. Rubinsztejn wychodzi z założenia, że świadomość jest swoistym uświadomieniem przez podmiot świata otaczającego i stosunków, w które dany podmiot z nimi wstępuje, w miarę tego, jak z życia i przeżywania wyodrębnia się refleksja nad otoczeniem i nad własnym życiem. Pojawia się wtedy wiedza o tym, co znajduje się poza świadomością. Rozwój świadomości człowieka związany jest w głównej mierze ze społecznie zorganizowaną działalnością ludzi, z czynnościami, jakie wykonują. Czynności te wymagają uświadomienia sobie ich rezultatów i w procesie ich wykonywania kształtuje się właśnie świadomość (Rubinsztejn 1961, s. 368-369).

K. Popper stwierdza, że jedną z korzyści, jaką daje świadomość, jest możliwość rozwiązywania niekonwencjonalnych problemów. Dobrym przykładem jest tutaj pisanie i inteligentna mowa, bowiem nieustannie trzeba konstruować nowe zdania. Poza tym świadomość jest konieczna do formułowania nowych teorii i przewidywań. To właśnie nieoczekiwane wydarzenie wymaga świadomej uwagi. Na koniec w przypadkach, kiedy stajemy twarzą w twarz z dwoma różnymi sposobami osiągnięcia celu, to właśnie świadomość jest potrzebna, aby podjąć decyzję (cyt. za: Scott 1999, s. 131).

Według E. Hartha świadomość jest rzeczywistym faktem mającym takie cechy charakterystyczne jak:

- selektywność - wynika z faktu, że z niezliczonej ilości zjawisk nerwowych tylko kilka odbija się w świadomości i można by przypuszczać, że wybrane zjawiska są uszeregowane według określonej hierarchii;

- ekskluzywność, inaczej wybiórczość - świadomość rejestruje w danym momencie tylko jeden sposób percepcji;

- tworzenie tańcuchów myślowych;

- jednolitość, inaczej tożsamość - w związku z faktem, że świadomość ogniskuje się na wybranych zjawiskach nerwowych, człowiek odczuwa swoją tożsamość, to znaczy czuje, że jest tą samą osobą, tak dziś, jak i wczoraj (Scott 1999, s. 144).

Podsumowując przedstawione koncepcje, można stwierdzić, że świadomość jest to swoista zdolność do zdawania sobie sprawy z własnego zachowania, najwyższy poziom rozwoju psychicznego pozwalający na odzwierciedlenie rzeczywistości, stan odczuwania i odbierania bodźców oraz zdolność do przeżywania doznań i stanów emocjonalnych (przykładowo związanych z ochroną środowiska - świadomość ekologiczna). 
Świadomość zatem to całokształt zobiektywizowanych idei obejmujących wyobrażenia, oceny, poglądy, teorie, wywierające wpływ na działania, zachowania człowieka (Januszek, Sikora 1997, s. 53).

Ze względu na podejmowany temat należy wyjaśnić również, jak pojmowana jest świadomość ekologiczna.

Na płaszczyźnie jednostki świadomość ekologiczna jest rezultatem procesu socjalizacji, w którym każda istota ludzka uczestniczy przez całe swoje świadome życie. Świadomość ta jest zjawiskiem subiektywnym, polegającym na pozyskiwaniu, uzupełnianiu wiedzy i wyobraźni ekologicznej z otaczającej rzeczywistości społecznej. Można zatem powiedzieć, że jest ona rezultatem indywidualnych przemyśleń, doznań, doświadczeń i umiejętności przekształcenia nabytej wiedzy ekologicznej w normy codziennego życia. Świadomość ekologiczna przejawia się też w funkcjonujących społecznie standardach pojmowania, przeżywania i wartościowania świata przyrody. Głównymi składnikami świadomości ekologicznej są ściśle określone treści, nastawienia oraz emocje dotyczące środowiska przyrodniczego, powiązane i wzajemnie przenikające się z innymi formami świadomości społecznej (Sobczyk 2000, s. 16).

Świadomość ekologiczna jest zespołem informacji i przekonań na temat środowiska przyrodniczego oraz postrzeganiem związków między stanem i charakterem środowiska przyrodniczego a warunkami i jakością życia człowieka (Burger 1986, s. $374-378)$.

Świadomość ekologiczna w ujęciu J. Frątczaka określana jest jako forma świadomości społecznej, odzwierciedlająca się w przeżyciach i myśleniu poszczególnych osób oraz funkcjonujących społecznie normach rozumienia i wartościowania środowiska przyrodniczego (Frątczak 2001).

Podstawowymi składnikami świadomości ekologicznej, jak wynika ze studium literatury przedmiotu, są:

- wiedza ekologiczna, która wyraża się w znajomości i zrozumieniu sposobu współistnienia człowieka i przyrody;

- wrażliwość ekologiczna, przejawiająca się w postaci emocjonalnego nastawienia do przyrody;

- postawy proekologiczne, czyli działania podejmowane na rzecz ochrony środowiska naturalnego.

Na płaszczyźnie świadomości ekologicznej realizowane są postawy oraz działania zarówno jednostek, jak też całych grup społecznych. Kreowanie i krzewienie wysokiego poziomu świadomości ekologicznej powinno odbywać się poprzez konsekwentne wdrażanie i realizację działań związanych z szeroko pojętą edukacją ekologiczną. Owa edukacja obejmuje kształtowanie świadomości i rozbudzanie zainteresowania ludzi wzajemnie powiązanymi ze sobą kwestiami ekonomicznymi, społecznymi, politycznymi i ekologicznymi oraz umożliwienie każdej jednostce zdobywania wiedzy i umiejętności niezbędnych do poprawy stanu środowiska przyrodniczego. Także tworzenie nowych wzorców zachowań, kształtowanie postaw, wartości i przekonań wszystkich ludzi, uwzględniających troskę o jakość i stan środowiska (zob.: Gender Expert 2013). 
W publikacjach i raportach odnoszących się do wyników badań na temat świadomości ekologicznej definiowana jest ona jako stopień zainteresowania tematyką ochrony środowiska, poziom aprobaty degradacji środowiska naturalnego jako ceny wzrostu ekonomicznego i poziom wiedzy na temat różnych metod pozytywnego wpływu na stan środowiska (TNS OBOP 2011, s. 16).

Wykazywany jest tutaj ścisły związek z ekonomią w kontekście kapitału naturalnego tworzącego odnawialne zasoby naturalne (np. lasy), nieodnawialne zasoby naturalne (np. ropa naftowa i minerały), ekosystemy, które podtrzymują i regenerują takie zasoby jak ziemia, powietrze i woda oraz zróżnicowane zasoby genetyczne (różnorodność biologiczna). Szczególnie w procesach gospodarowania i kosztów ochrony ekosystemów. Jako przykład można podać w Polsce kwestię nieopłacalnego wcześniej wydobycia tzw. gazu łupkowego metodą nowej technologii szczelinowania. W obliczu kryzysu środowiskowego i wyczerpywania istotnych surowców naturalnych zagadnienie wykorzystania zasobów naturalnych, które generują korzyści kapitału, nabiera szczególnego znaczenia. Przyjęcie wzoru rozwoju zrównoważonego przez agendy międzynarodowe i rządy wielu państw wiąże się $\mathrm{z}$ zaakceptowaniem pewnych ograniczeń $\mathrm{w}$ korzystaniu $\mathrm{z}$ kapitału naturalnego, które mają zagwarantować, że możliwości wykorzystania zasobów środowiskowych przyszłych pokoleń nie zostaną uszczuplone. Zdaniem Górnickiego polityka wprowadzania zasad zrównoważonego rozwoju poprzez promowanie i dofinansowanie proekologicznych rozwiązań gospodarczych może się przyczyniać do tego, że wcześniej nieopłacalne z ekonomicznego punktu widzenia stają się rentowne, tak jak to ma miejsce np. $\mathrm{z}$ wykorzystaniem odnawialnych źródeł energii (Górnicki 2012, s. 272).

Świadomość ekologiczna to również stopień, w jakim jednostki interesują się tematem środowiska naturalnego i jego ochrony, jakie są ich przekonania na temat degradacji środowiska oraz jaką mają wiedzę o możliwych działaniach wspierających jego ochronę. Zachowania ekologiczne oznaczają działania pozytywnie wpływające na stan środowiska naturalnego, które mogą być podjęte przez każdego człowieka (Gender Experts 2013, s. 5).

$\mathrm{W}$ związku z powyższymi teoretycznymi rozważaniami autorki opracowania, podsumowując, skonstruowały definicję świadomości ekologicznej. I tak świadomość ekologiczną należy rozumieć jako zbiór poglądów o środowisku przyrodniczym i jego ochronie, dotyczy ona wiedzy na temat ekologii i oceny wszelkich działań wpływających na ochronę czy degradację środowiska naturalnego.

\section{Świadomość ekologiczna młodych ludzi - odniesienie empiryczne}

W Polsce od szeregu lat prowadzone są badania dotyczące świadomości ekologicznej jej mieszkańców. Głównie sprowadzają się do obszarów wiedzy i nastawienia do środowiska naturalnego, jego ochrony, gospodarki odpadami, tj. zachowań i postaw związanych ze sposobami, w jaki Polacy pozbywają się śmieci, jak oszczędzają energię $\mathrm{w}$ gospodarstwach domowych, w konfrontacji z codzienną praktyką $\mathrm{w}$ tym zakresie. Badaniom poddawane są również zachowania konsumenckie, tj. troska o środowisko naturalne przejawiająca się w szeregu codzien- 
nych czynności, między innymi w trakcie robienia zakupów czy przy wyborze środków transportu.

Podobnie autorki opracowania wzięły pod uwagę powyższe obszary w swoich badaniach dotyczących świadomości ekologicznej młodzieży, co dało możliwość porównań czy szerszych odniesień. Analizie poddano opinie młodzieży w wieku od 20 do 23 lat, która w literaturze przedmiotu przedstawiana jest jako pokolenie o specyficznych wymaganiach konsumenckich i pracowniczych (Robak 2015, s. 72). Również dla zobrazowania analizy podano przykłady wypowiedzi w oryginalnym brzmieniu (cytaty).

Pierwszym istotnym pytaniem w niniejszych badaniach wydało się być - jak młodzież pojmuje wiedzę ekologiczną? Odpowiedzi uzyskane w pytaniach otwartych miały szeroki wachlarz, i tak między innymi respondenci odpowiadali:

- „Wiedzieć, co jest zdrowe i bezpieczne, jak dbać o środowisko”.

- „Wiedza ekologiczna ma dla mnie duże znaczenie, biorę udziat w różnego rodzaju działaniach proekologicznych w moim regionie".

- „Wiedza ekologiczna pozwala dokonać właściwych wyborów podczas zakupów oraz podczas zwyktych domowych czynności, np. gotowania czy kapieli”.

Jak pokazują inne badania, Polacy do środowiska i jego ochrony nastawieni są pozytywnie - przykładowo $91 \%$ uważa, że ochrona przyrody powinna być priorytetowym działaniem człowieka, a $84 \%$ sądzi, że człowiek ma wpływ poprzez swoje indywidualne działania na stan zasobów naturalnych. Pomimo takich deklaracji $56 \%$ badanych w życiu codziennym nie zastanawia się nad tym, czy to, co robi, ma wpływ na środowisko. Jest to jeden z wielu przykładów, kiedy okazuje się, że dla części osób pozytywny stosunek do ekologii nie przekłada się na zachowania. $\mathrm{Z}$ jednej strony deklarują odpowiedzialność za stan środowiska, z drugiej w codziennym życiu nie zawsze zwracają na to uwagę (TNS OBOP 2011, s. 5). W przypadku badanej przez autorki młodzieży najczęstszym dla nich źródłem wiedzy ekologicznej, są:

- popularne media (56\%), TV (programy popularnonaukowe, przyrodnicze), prasa, radio (,, $W$ telewizji teraz dużo mówi się na ten temat, prowadzi programy ekologiczne");

- dotychczasowa edukacja (,,Ze szkoty”) (15\%);

- czasopisma, książki,

- Internet (7\%);

- doświadczenia osobiste $(6 \%)$;

- bliskie otoczenie (krewni, znajomi itp.).

Wartości te są porównywalne do tych uzyskanych w prowadzonych ogólnopolskich badaniach nad świadomością ekologiczną Polaków (zob.: Bołtromiuk, Burger 2008).

Zgodnie z założeniami badawczymi autorki przeanalizowały uzyskane opinie $\mathrm{w}$ obszarze racjonalnego wykorzystywania zasobów naturalnych (tj. paliw, metali, wody, gleby, gazu itp.). Można było zaobserwować kilka grup, np.:

- Stosunek do gospodarowania zasobami (woda, energia elektryczna): 
- „Staram się oszczędzać wodę czy energię elektryczna, gaszę urządzenia, gdy z nich nie korzystam";

- „Wyłaczam ładowarkę z pradu i zasilacze, gdy z nich nie korzystam”;

- „Wytaczam urządzenia z gniazdek, także na noc”;

- „Jeżeli moge, staram się brać prysznic zamiast kapieli w wannie, przez co oszczędzam wodę".

- Powtórne używanie (recykling):

- „Wykorzystuję ponownie różne stare rzeczy”;

- „Wykorzystuje stare rzeczy do stworzenia nowych, np. z ptyt CD/DVD zrobitem sobie stojak na plyty";

- „Zwracam uwage na opakowania, żeby byty wielokrotnego użytku”;

- „Podczas zakupów zwracam uwage na to, z jakich tworzyw sq opakowania, $i$ kiedy kupuje $w$ plastikowych czy szklanych, to wiem, ize należy je zutylizować; staram się nie wybierać foliowych opakowań, które rozkładaja się setki lat".

Najczęściej powtarzają się wypowiedzi o oszczędzaniu wody (zakręcanie kranu podczas mycia zębów, prysznic zamiast kąpieli w wannie, nawet podlewanie roślin zebraną wcześniej deszczówką itp.) i energii elektrycznej (wyłączanie światła w pomieszczeniach, w których się nie przebywa, ładowarek czy innych urządzeń elektrycznych).

Można tutaj np. przytoczyć badania porównujące postawy oszczędzania energii w gospodarstwie domowym z codzienną praktyką Polaków w tym zakresie. Wskazują one, iż gaszenie światła w pustych pomieszczeniach - uznane za najlepszy sposób oszczędzania energii w domu - praktykują prawie wszyscy badani (99\%), przy czym $2 / 3$ robi to zawsze, zaś $29 \%$ przyznało, iż robi to często. Widać tu, że podstawą takich postaw jest kwestia ekonomiczna, widać również oczywistą spójność między deklaracją a codzienną praktyką - respondenci robią to, co ich zdaniem przyniesie im największe oszczędności. Równie dużo osób (91\%) wyjmuje ładowarkę po zakończeniu ładowania telefonu, przy czym prawie $2 / 3$ robi to zawsze, a prawie $1 / 5$ często. Zdecydowana większość badanych (87\%) deklaruje używanie żarówek energooszczędnych. Aż $89 \%$ badanych wyłącza nieużywany sprzęt, jednak co czwarta osoba robi to rzadko. Nieco mniejsza aktywność badanych odnośnie wyłączania sprzętu może wynikać z faktu, iż ważniejsza jest w tym momencie dla respondentów wygoda niż ewentualne oszczędności energii, które uważane są raczej za niewielkie (jedynie $1 / 4$ badanych uznała, że wyłączanie sprzętu pozwala zaoszczędzić dużo energii) (Stanaszek, Tędziagolska 2011, s. 35-36).

Badana młodzież deklaruje również aktywność w kwestii gospodarowania odpadami, segregacji śmieci (bardzo często i często (65\%)). Można stwierdzić, że procentowo jest to zbliżone do tego, co wykazują ogólnokrajowe badania, gdzie w ciągu ostatnich czterech lat regularna segregacja odpadów systematycznie rośnie. W roku 2014 odsetek osób regularnie segregujących odpady wynosi $68 \%$ (TNS 2014). Większość ankietowanych deklaruje segregację odpadów, wykazując się wiedzą na temat konieczności segregacji i znajomością kolorów pojemników na poszczególne rodzaje odpadów: 
„,W domu posiadam kosze do segregacji śmieci i segreguje odpady: szkto makulature, plastiki, popiót, bioodpady".

Zachowania konsumenckie wspierające ochronę środowiska są ograniczone, Polacy dbają o ochronę środowiska, korzystając z toreb wielokrotnego użytku (zawsze lub często robi to ponad $70 \%$ osób), a rzadziej zwracają uwagę na oznaczenia ekologiczne (mniej niż 40\%) (TNS 2014). Wśród badanych młodych ludzi zanotowano deklaracje proekologicznych zachowań konsumenckich podczas zakupów:

- „Zabieram torbę wielokrotnego użytku, a warzywa i owoce kupuję na targu u zaufanych gospodarzy";

- „Staram się nie kupować w plastikach”;

- „Na zakupy staram się zabierać swoją torbę, dzięki czemu nie muszę kupować reklamówek";

- „Na zakupy najczęściej chodzę na nogach, bo mam niedaleko od siebie sklepy”;

- „Zwracam uwagę tylko na niektóre, czy są eko”;

- „Zazwyczaj nie kupuję produktów eko; jeżeli mam mało zakupów, to nie biorę torby; jeżeli mam blisko do sklepu, to idę na nogach”.

Zdaniem ankietowanych środowisko przyrodnicze warto chronić przede wszystkim w trosce o zdrowie własne i najbliższych oraz przyszłych pokoleń.

\section{Podsumowanie}

Troska o środowisko naturalne u większości Polaków niestety przegrywa z rachunkiem ekonomicznym. Nie są oni gotowi przeznaczać więcej swoich dochodów na rozwiązania proekologiczne, np. czystą energię. Motorem do oszczędzania energii czy wody jest bardziej troska o domowy budżet niż świadoma postawa ekologiczna. Ponadto - jak wykazują badania, w tym i przytoczone powyżej środowisko przyrodnicze warto chronić przede wszystkim w trosce o zdrowie własne i najbliższych oraz przyszłych pokoleń. Co też obrazują przytoczone wypowiedzi badanych:

- „Staram się racjonalnie wykorzystywać zasoby naturalne, bo jak wiadomo, nie są wieczne";

— „Każdy chciałby żyć w czystym i zdrowym środowisku i oddychać świeżym powietrzem";

- „Ludzie są przecież częścią przyrody, dlatego trzeba o nią dbać”.

Mając na uwadze powyższe rozważania i analizy, pozostaje mieć nadzieję, że świadomość ekologiczna młodzieży daje pozytywną perspektywę dla środowiska przyrodniczego. 


\section{Literatura}

1. Blackburn S. (1997), Oksfordzki słownik filozoficzny, Książka i Wiedza, Warszawa.

2. Bobryk J. (2004), Świadomość człowieka w epoce mediów elektronicznych, Polskie Towarzystwo Semiotyczne, Warszawa.

3. Bołtromiuk A., Burger T. (2008), Polacy $w$ zwierciadle ekologicznym. Raport z badań nad świadomościq ekologiczna Polaków w 2008 r., http://www.ine-isd.org.pl/wp-content/uploads/ pdf/polacy_w_zwierciadle_ekol.pdf (dostęp: 10.09.2017).

4. Burger T. (1986), Uwagi o świadomości ekologicznej, „Przegląd Powszechny”, nr 12, s. 374-388.

5. Crick F. (1997), Zdumiewająca hipoteza. Czyli nauka w poszukiwaniu duszy, Prószyński i S-ka, Warszawa.

6. Frątczak J. (2001), Świadomość ekologiczna dzieci, młodzieży i dorosłych w aspekcie edukacji szkolnej i nieszkolnej, Wydawnictwo WSP w Bydgoszczy, Bydgoszcz.

7. Gender Experts (2013), Podnoszenie świadomości ekologicznej, http://www.genderexperts. files.wordpress.com/2013/05/eko_warsztat.pdf (dostęp: 10.09.2017).

8. Górnicki K. (2012), Kapitat naturalny jako kategoria socjologiczna, „Pogranicze. Studia Społeczne", t. 20, s. 271-296.

9. Gregory R.L. (2000), Mózg i maszyny, Prószyński i S-ka, Warszawa.

10. Hebb D.O. (1949), The Organization of Behavior. A Neuropsychological Theory, John Wiley \& Sons, New York.

11. Januszek H., Sikora J. (1997), Podstawy socjologii, Wydawnictwo Akademii Ekonomicznej w Poznaniu, Poznań.

12. Nagel T. (2006), Świadomość a obiektywna rzeczywistość, „Znak”, nr 2, s. 73-80.

13. PBS (2013), Badanie świadomości i zachowań ekologicznych mieszkańców Polski, PBS, Sopot, 28 października 2013,

14. https://www.mos.gov.pl/g2/big/2013_12/ee41d9c93bc700729faf03103120a38c.pdf (dostęp: 10.09.2017).

15. Robak E. (2015), Nowe pokolenie na rynku pracy jako wyzwanie dla zarzadzajacych nowoczesnymi organizacjami, [w:] Bazan-Bulanda A., Robak E., Kwiatek A. (red.), Udziat pracowników w zarządzaniu nowoczesnymi organizacjami gospodarczymi, Wydawnictwo Wydziału Zarządzania Politechniki Częstochowskiej, Częstochowa, s. 70-82.

16. Rubinsztejn S.L. (1961), Byt i świadomość, Książka i Wiedza, Warszawa.

17. Santayana G. (1955), The Sense of Beauty, Modern Library, New York.

18. Scott A. (1999), Schody do umystu, Wydawnictwa Naukowo-Techniczne, Warszawa.

19. Sobczyk W. (2000), Edukacja ekologiczna i prozdrowotna, Wydawnictwo Naukowe Akademii Pedagogicznej, Kraków.

20. Stanaszek A., Tędziagolska M. (2011), Badanie świadomości ekologicznej Polaków 2010 ze szczególnym uwzględnieniem energetyki przyjaznej środowisku, Narodowy Fundusz Ochrony Środowiska i Gospodarki Wodnej, Instytut na rzecz Ekorozwoju, Warszawa.

21. Sutherland S. (1996), The International Dictionary of Psychology, Crossroad, New York.

22. TNS (2014), Badanie świadomości i zachowań ekologicznych mieszkańców Polski, TNS, listopad 2014, https://www.mos.gov.pl/g2/big/2014_12/fe749deb7e1414bf1c4afbc65483 00f9.pdf (dostęp: 10.09.2017).

23. TNS OBOP (2011), Badania świadomości i zachowań ekologicznych mieszkańców Polski, (2011), TNS OBOP, Warszawa, grudzień 2011, https://www.mos.gov.pl/fileadmin/ user_upload/Badanie_swiadomosci_i_zachowan_ekologicznych_mieszkancow_Polski_ badanie_trackingowe_2011_.pdf (dostęp: 10.09.2017).

24. Znaniecki F. (1938), Socjologiczne podstawy ekologii ludzkiej, „Ruch Prawniczy Ekonomiczny i Socjologiczny", nr 1, s. 89-119. 


\section{ECOLOGICAL AWARENESS OF YOUNG PEOPLE}

Abstract: The development has been addressed the issue of the role and importance of environmental awareness for today's youth. The existing all kinds of environmental projects implemented since the lowest degrees of education and numerous social campaigns, lead to believe that the majority of young people should have at least the minimum range of knowledge on this topic. The authors want to based on this assumption look at the answers to the questions: what is the degree of environmental awareness of young people, i.e. What is the importance of ecological knowledge for it, and how much is applied by them in practice? Particularly in the areas of IE. rational use of resources, ecological conservation, waste management, once the overall attitude to ecology.

Keywords: consciousness, environmental awareness, environmental knowledge 